\title{
STUDI OPTIMALISASI KUALITAS SISTEM CATU DAYA TERINTEGRASI PADA PT. TELKOM STASIUN BUMI SORONG
}

\author{
Markus Dwiyanto Tobi, ST., MT, dan Vina Natalia Van Harling, S.Si.,M.Pd \\ Politeknik Katolik Saint Paul Sorong \\ Email : dwiyanto@poltekstpaul.ac.id; vina.nathalia@poltekstpaul.ac.id
}

\begin{abstract}
Abstrak
Sistem catu daya pada industri Infokom menggunakan konfigurasi yang cukup rumit agar menjamin kehandalan dan kelangsungan catu daya itu sendiri, dengan digunakannya beberapa perangkat yang bersifat induktif seperti rectifier, inverter, UPS (Uninterruptible Power Supply), AC (Air Conditioner), kompresor, motor pompa, lampu TL (Tube Lamp) dan lain sebagainya akan menyebabkan beda fasa antara arus dan tegangan yang signifikan sehingga mengakibatkan turunnya faktor daya pada instalasi listrik. Bertolak dari alasan ini, maka dipandang perlu untuk dilakukan suatu analisa menyeluruh dalam suatu sistem catu daya dengan tujuan mencari solusi yang tepat dalam hal optimalisasi kualitas catu daya dan juga sebuah sistem perbaikan kualitas arus yang terintegrasi sehingga fungsi-fungsi kerja tidak saling mengurangi dalam hal perbaikan kualitas arus listrik. Untuk itu, peneliti mencoba melakukan studi terhadap kualitas sistem catu daya pada aplikasi industri informasi/IT dan komunikasi (tepatnya di PT. Telkom Stasiun Bumi Sorong) yang mungkin dapat menjadi pertimbangan bagi PT. Telkom sendiri untuk melakukan perbaikan kualitas catuan ke bebannya.
\end{abstract}

\section{Kata Kunci : Optimalisasi, Supply Energy, Kualitas Daya Listrik, Orde Harmonisa}

\section{PENDAHULUAN}

\subsection{Latar Belakang Masalah}

Dewasa ini, dunia pada umumnya dihadapkan pada masalah ancaman global warming yaitu fenomena pemanasan global akibat rusaknya lapisan ozon oleh gas kimia pembuangan berupa emisi karbon dari industri, kendaraan bermotor maupun residensial. Banyak hal telah diupayakan untuk mengatasi masalah ini baik secara langsung maupun tak langsung. Di bidang energi sendiri merupakan hal yang paling concern disoroti, apakah itu dengan mencari alternatif bahan bakar ramah lingkungan ataupun melakukan penghematan energi.

Segmen pemakai listrik yang paling memperhatikan hal ini biasanya adalah pemakai listrik berkapasitas besar dalam skala puluhan maupun ratusan kilowatt. Industri informasi dan komunikasi (Infokom) yang menggunakan banyak komponen mikroprosesor, terlepas dari tuntutan penghematan energi juga dituntut untuk memberikan supply listrik berkualitas yang sesuai spesifikasi.

Masalah yang dihadapi selanjutnya, dengan adanya sistem manipulasi arus dan tegangan untuk keperluan suplai maupun penyimpanan/akumulasi arus, maka tentunya akan terdapat banyak komponen-komponen pembangkit/pengatur denyut frekuensi (seperti variable frequency driver, watt driver, variable switch driver, dan lain-lain) yang efeknya akan menciptakan distorsi harmonisa secara tergabung yang mengalir ke sistem instalasi secara keseluruhan bahkan ke jaringan eksternal. Harmonisa ini berupa riak frekuensi pada gelombang sinus tegangan ac (alternating current) yang frekuensinya lebih tinggi dari gelombang sinus aslinya dan menyebabkan panas yang tidak normal pada saluran maupun pada beban, sehingga terjadi anomali system overload 
padahal beban yang digunakan masih di bawah 70\% dari kapasitas maksimum.

Selain itu secara umum, beberapa faktor eksternal dan internal, seperti kondisi ataupun kualitas arus jala-jala, resiko petir, unbalanced load, unbalance phase, unstable voltage, arus transien dan lain sebagainya turut mempengaruhi kualitas arus yang dikonsumsi oleh beban. Di kota Sorong sendiri untuk kualitas suplai dari jala-jala masih di bawah standar dengan seringnya kita menjumpai ketidakstabilan tegangan, phase loss, brown out dan $\cos \varphi$ rendah. Pada akhirnya masalah-masalah ini disamping mengganggu operasional juga akan menurunkan umur operasi perangkat yang dicatu.

Masing-masing masalah polusi tenaga listrik yang dipaparkan di atas telah mempunyai solusi tersendiri, misalnya dengan pemasangan capacitor bank, filter harmonis, AVR (Automatic Voltage Regulator) dan arester. Tetapi timbul juga efek dari masing-masing komponen tersebut yang saling mengeliminasi fungsi kerja komponen lainnya, seperti capacitor bank yang ternyata juga menyebabkan harmonisa yang cukup besar (sebagai efek lanjutan dari proses resonansi kapasitor).

\subsection{Perumusan Masalah}

1. Mengetahui tingkat polusi tenaga listrik yang terjadi dalam sistem catu daya pada PT. Telkom Stasiun Bumi Sorong

2. Mengetahui metode penghematan dan efisiensi penggunaan daya serta umur kerja peralatan listrik (beban)

\section{Landasan teori}

\subsection{Beberapa Gangguan dan Indikator Parameter Kualitas Kelistrikan}

Secara umum di Indonesia masalah power quality belum sampai menjadi isu perhatian secara nasional dan detail, beberapa hal memang sudah cukup peduli dari pengguna namun masih dalam kaitan tegangan rendah atau tidak stabil atau pemadaman listrik. Padahal energy quality bukan hanya masalah tegangan saja atau terputusnya catuan tetapi menyangkut karakteristik parameter kelistrikannya seperti arus dan frekuensi kaitan dengan harmonisa, arus bocor, tegangan transien, sag/dips \& surge, swell, ripple, noise dan sebagainya yang dapat merusakan peralatan dan mengurangi umur perangkat.

\subsection{Penanggulangan Gangguan Kelistrikan}

Perbedaan siklus aktif pada peralatan listrik dan variasi pola pekerjaan dalam suatu gedung instalasi menyebabkan perubahan pola pembebanan secara terus menerus. Sebagai contoh sebuah gedung kantor yang besar, dapat berubah pola pembebanannya sampai ribuan kali per tahun, yang berakibat pada perilaku harmonisa (spektrum arus resultan harmonisa) pada sistem instalasi berubah secara konstan. Perilaku harmonisa pada peralatan IT (Information Technology) tidak jauh berbeda terutama pada harmonisa orde signifikan ke tiga, ke lima dan seterusnya. Operasi siklus aktif singkat peralatan seperti lift dan peralatan mekanik lainnya menyebabkan variasi tegangan lokal bertambah ke beban jenis ini dari sistem distribusi. Dengan begitu, masalah kualitas daya harus diperhitungkan dan dimonitor dengan penuh perhatian. Begitu pula pada perancangan atau desain awal suatu sistem instalasi dan sistem power quality pada bangunan gedung, yang sangat sulit untuk diperhitungkan dikarenakan pada umumnya ukuran beban akhir tidak dapat diketahui. Beberapa cara yang dapat dilakukan untuk menanggulangi gangguan kelistrikan yaitu:

a. Surge Protection

b. Automatic Voltage Stabilizer / Automatic Voltage Regulator

c. Backup Generator

d. UPS (Un-interruptible Power Supply)

e. Capacitor Bank

f. Passive Filters

g. Active Conditioner

h. Upsized Neutral 
i. Antisipasi Penurunan Kemampuan Perangkat (Equipment Derating)

j. Dedicated Circuits (Pemisahan Sirkit Tersendiri)

k. Total Rewire (Perkawatan Ulang secara Total)

1. Meshed Earth (Pembumian Terhubung Jala)

\section{PEMBAHASAN}

\subsection{Konfigurasi Sistem Catu Daya pada PT.} Telkom Stasiun Bumi Sorong

Secara garis besar, konfigurasi sistem catu daya di Stasiun Bumi Sorong dapat digambarkan sebagai berikut :

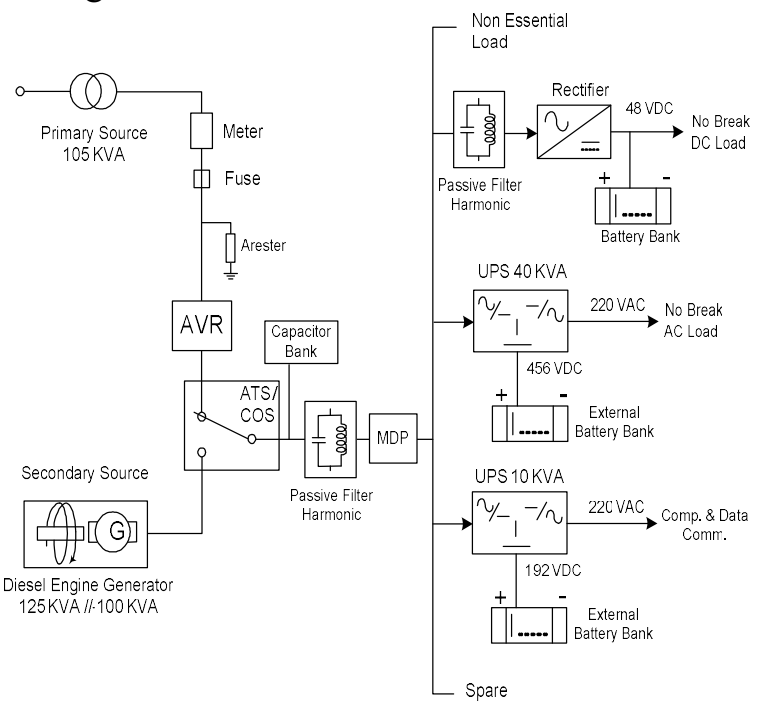

Gambar 3.1. Diagram Sistem Instalasi Catu Daya Stasiun Bumi Sorong

Data spesifikasi dan pengukuran sistem catu daya pada stasiun bumi Sorong dapat diuraikan sebagai berikut :

1. Daya Utama:
- PLN
$105 \mathrm{KVA}$
- DEG :
$125 \mathrm{KVA} / / 100 \mathrm{KVA}$

2. Arester Utama, kapasitas $100 \mathrm{kA}$

3. Capacitor Bank

Kapasitas : 105 KVAR

Cos $\varphi$ terukur : $0.99 / 99 \%$ (capacitor on) 0.82 / 82\% (capacitor off)

4. Main Distribution Point (MDP)
Test Beban Penuh :

Phasa R : 26.28 A

Phasa S : $29.67 \mathrm{~A}$

Phasa T : $27.11 \mathrm{~A}$

Sampai dengan saat ini, perilaku pembebanan masih dapat dikatakan seimbang/balance antar fasa. Dalam kondisi normal, arus ketiga fasa tersebut hampir sama, yaitu di kisaran nilai $16 \mathrm{~A}$.

5. a. UPS Beban ac No Break

Kapasitas : $40 \mathrm{KVA}, 3$ fasa

Eksternal Batt. : 38 cell @ 12 Vdc,60

$\mathrm{AH}= \pm 456 \mathrm{Vdc}$

Kapasitas terpakai fasa R-N : $5 \%$

Kapasitas terpakai fasa S-N : $11 \%$

Kapasitas terpakai fasa T-N : $8 \%$

b. UPS Beban Komputer dan Komunikasi Data

Kapasitas $\quad: \quad 10 \mathrm{KVA}, 1$ fasa

Kapasitas terpakai : $\quad 18 \%$

Eksternal Batt. : 16 cell @ 12

$\mathrm{Vdc}, 38 \mathrm{AH}= \pm 192 \mathrm{Vdc}$

6. Rectifier 3 fasa

Kapasitas : 3 modul @40 A

Kapasitas terpakai modul 1 : $\quad 8.3 \mathrm{~A}$

Kapasitas terpakai modul 2: $\quad 6.8$ A

Kapasitas terpakai modul 3 : $\quad 9.2 \mathrm{~A}$

Batterry Bank : 24 cell @ 2 V, $150 \mathrm{AH}= \pm$ $48 \mathrm{Vdc}$

\subsection{Beberapa Pengukuran Parameter Kualitas Daya}

Pada umumnya beberapa alat ukur dapat digunakan untuk mengukur beberapa parameter kualitas daya yaitu :

- Multimeter True RMS (Arus, Tegangan, Tahanan, Impedansi)

- Tang Ampere True RMS (Arus, Tegangan, Tahanan, Impedansi)

- Power Analyzer (Daya, THD)

- Spectrum Analyzer (Spektrum Frekuensi, Daya, Lebar Pita Frekuensi) 
- Oscilloscope (Bentuk Gelombang, Arus Puncak, Tegangan Puncak, Frekuensi)

\subsubsection{Pengukuran THD Sistem Instalasi Telkom Stasiun Bumi Sorong}

Pengukuran ini dilakukan dengan menggunakan spectrum analyzer dengan titik ukur pada terminal ukur output panel ATS (Automatic Transition Switch) atau COS (Change Over Switch). THD ini dapat diukur dengan referensi arus, tegangan ataupun daya. Dalam pengukuran ini hanya bisa diukur tegangan mengingat test point yang disediakan cuma untuk tegangan dan akan sangat beresiko jika pengukuran spectrum dipaksakan untuk mengukur arus ataupun daya. Perlu diketahui pula bahwa pengukuran tegangan ini dilakukan antara sampel fasa $\mathrm{R}$ dengan titik netral untuk catuan jala-jala (PLN) pada saat beban maksimal. Diagram pengukuran dapat dilihat pada gambar berikut :

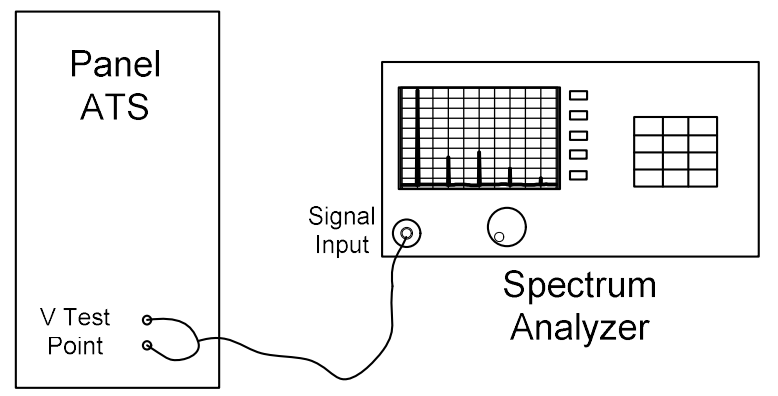

Gambar 3.2. Pengukuran Spektrum Tegangan Sistem Instalasi

Adapun gambar display spectrum analyzer hasil pengukuran di atas dapat dilihat pada gambar di bawah ini, beserta setting alat ukur dan hasil pengukurannya. Pengukuran dengan spectrum analyzer ini dibatasi hanya pada frekuensi $450 \mathrm{~Hz}$ saja (harmonisa orde ke-9) karena harmonisa orde di atasnya $(11,13$, dan seterusnya) terukur tegangan di bawah 1 Volt sampai dengan 0 (nol) Volt.

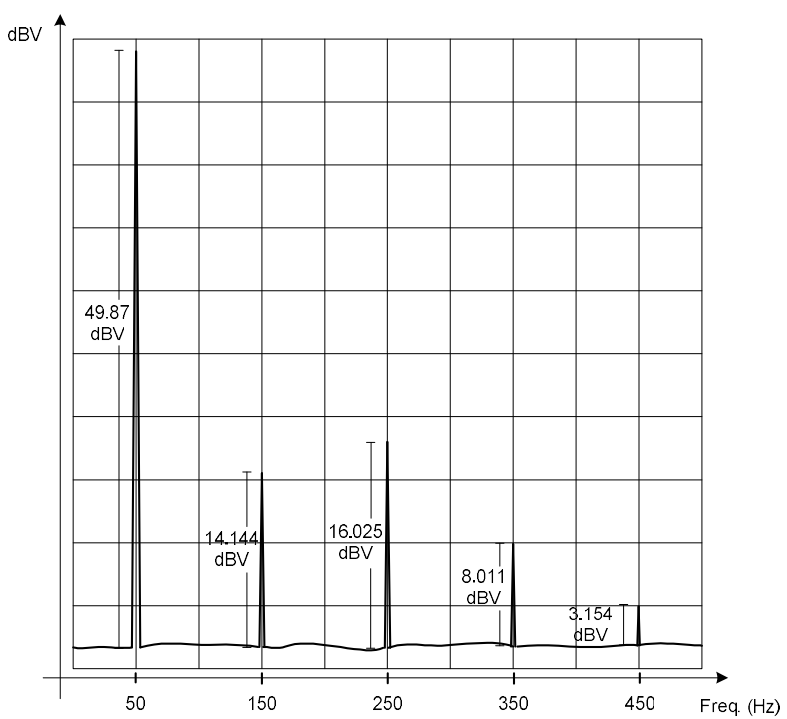

Gambar 3.3. Display Spectrum Analyzer Hasil Pengukuran Spektrum Tegangan

Setting alat ukur Spectrum Analyzer adalah sebagai berikut :

$$
\begin{array}{rlll}
\text { Center Frequency } & =250 \mathrm{~Hz} \text { Video } & B W \\
& =100 \mathrm{~Hz} & \\
\mathrm{~dB} \log / \mathrm{div} & =5 \quad \text { Resolution } & B W \\
& =30 \mathrm{kHz} & \\
\text { Span } & =500 \quad \mathrm{~Hz} \quad \text { Sweep } \\
& =1 \text { second } &
\end{array}
$$

Sedangkan hasil pengukuran dapat dilihat pada uraian di bawah ini :

- $\mathrm{C} / \mathrm{N}$ Tegangan Dasar (frekuensi $50 \mathrm{~Hz}$ ), Vf $=49.87 \mathrm{dBV}$

- $\mathrm{C} / \mathrm{N}$ Tegangan Harmonik Orde 2, 4, 6 dan seterusnya (pada frekuensi $100 \mathrm{~Hz}, 200 \mathrm{~Hz}$, $300 \mathrm{~Hz}$, dan seterusnya), V2, V4, V6, .... = $0 \mathrm{dBV}$

- $\mathrm{C} / \mathrm{N}$ Tegangan Harmonik Orde 3 (frekuensi $150 \mathrm{~Hz}), \mathrm{V} 3=14.114 \mathrm{dBV}$

- $\mathrm{C} / \mathrm{N}$ Tegangan Harmonik Orde 5 (frekuensi $250 \mathrm{~Hz}$ ), V5 = $16.025 \mathrm{dBV}$

- $\mathrm{C} / \mathrm{N}$ Tegangan Harmonik Orde 7 (frekuensi $350 \mathrm{~Hz}$ ), V7 = $8.011 \mathrm{dBV}$

- $\mathrm{C} / \mathrm{N}$ Tegangan Harmonik Orde 9 (frekuensi $450 \mathrm{~Hz}$ ), V9 = $3.154 \mathrm{dBV}$

Jika diubah dari bentuk decibell ke voltase biasa, maka: 
$\mathrm{Vf}=$ inv $\log \frac{49.87}{20}=$ inv $\log 2.4935=311.53 \mathrm{~V}$

$\mathrm{V} 3=$ inv $\log \frac{14.114}{20}=$ inv $\log 0.706=5.078 \mathrm{~V}$

$\mathrm{V} 5=$ inv $\log \frac{16.025}{20}=$ inv $\log 0.801=6.328 \mathrm{~V}$

$\mathrm{V} 7=$ inv $\log \frac{8.011}{20}=$ inv $\log 0.4001=2.515 \mathrm{~V}$

$\mathrm{V} 9=$ inv $\log \frac{3.154}{20}=$ inv $\log 0.1577=1.438 \mathrm{~V}$

Dengan menganggap bahwa harmonisa orde signifikan hanyalah orde 3,5, 7 dan 9 (sedangkan harmonisa orde selanjutnya bernilai di bawah 1 Volt dan dapat diabaikan), maka perhitungan THD di bawah hanya memperhitungkan tegangan harmonisa keempat orde tersebut.

$$
\begin{aligned}
\mathrm{THD}_{\mathrm{V}} & =\frac{\sqrt{\mathrm{V}_{3}^{2}+\mathrm{V}_{5}^{2}+\mathrm{V}_{7}^{2}+\mathrm{V}_{9}^{2}}}{\mathrm{Vf}} \\
= & \frac{\sqrt{5.078^{2}+6.328^{2}+2.515^{2}+1.438^{2}}}{311.53} \\
= & \frac{\sqrt{74.223}}{311.53} \\
= & 0.02765
\end{aligned}
$$

Jika dipersentasikan maka \% THD adalah:

$$
\begin{aligned}
\% \mathrm{THD}_{\mathrm{V}} & =0.02765 \times 100 \% \\
& =2.765 \%
\end{aligned}
$$

Dalam industri telekomunikasi/infokom, dipersyaratkan \% THD maksimal dalam suatu sistem instalasi adalah $5 \%$. Sedangkan yang terukur di lokasi stasiun bumi Sorong adalah $2.765 \%$, sehingga dapat dikatakan masih dalam kategori normal. Hal ini mungkin dikarenakan oleh penggunaan filter harmonik secara terpusat untuk memfilter harmonik dari beban nonessential, seperti lampu TL, TV, monitor komputer jenis CRT dan sebagainya. Dan secara khusus untuk beban essential, (seperti rectifier, high power amplifier, variable frequency driver dan sebagainya) digunakan UPS yang di dalamnya telah ada fungsi filter harmonik dan penstabilan tegangan.

\subsubsection{Perekaman Sampel Stabilitas Tegangan}

Pengukuran ini juga dilakukan dengan menggunakan spectrum analyzer, dengan cara mengambil sampel interval waktu pada saat transisi pembebanan minimal selama satu jam. Untuk itu digunakan fitur "max hold" pada spectrum analyzer untuk merekam terjadinya fluktuasi frekuensi ataupun tegangan pada sistem instalasi. Adapun cara pengukurannya adalah sama dengan pada saat pengukuran THD di atas tetapi membutuhkan waktu perekaman paling tidak selama satu jam atau lebih. Pengukuran ini dilakukan selama 90 menit mulai pukul 17.30 sampai dengan 19.00 waktu setempat dengan memperhatikan saat transisi kondisi pembebanan dari beban normal ke beban maksimal. Diagram pengukurannya dapat dilihat pada gambar di bawah ini :

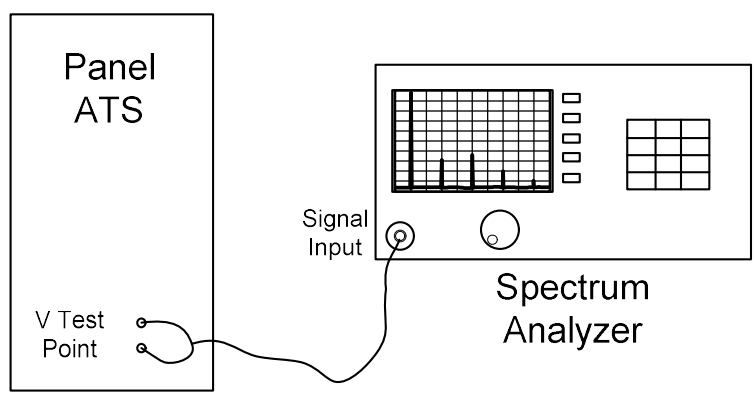

\section{Gambar 3.4. Perekaman Fluktuasi Frekuensi dan Tegangan Sistem Instalasi}

Hasil pengukuran ini dapat dilihat pada gambar di bawah, dimana tampak rekaman fluktuasi frekuensi yang telah bergeser sejauh kurang lebih $2 \mathrm{~Hz}$ atau $1 \mathrm{~Hz}$ lebih rendah dan $1 \mathrm{~Hz}$ lebih tinggi, selama selang waktu 90 menit. Fluktuasi frekuensi ini masih dalam batas toleransi yang ditetapkan yaitu $\pm 1.5 \mathrm{~Hz}$ atau selisih $3 \mathrm{~Hz}$ dan mungkin disebabkan oleh 
kenaikan arus pada saat beban bertambah. Sedangkan untuk fluktuasi tegangan dapat dikatakan bahwa respon tegangan cukup stabil dalam menanggapi perubahan kondisi pembebanan, walaupun terdapat sedikit riak yang mungkin diakibatkan oleh pensaklaran bebanbeban yang berat.

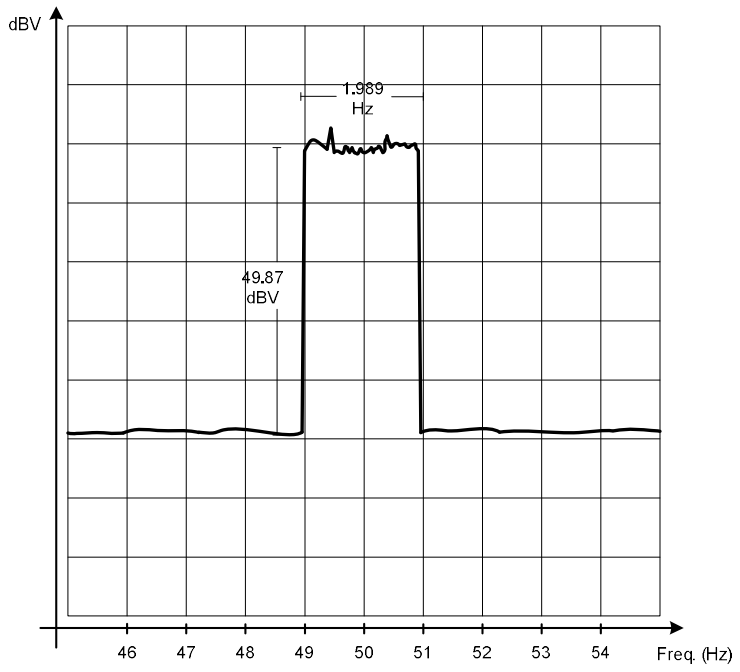

Gambar 3.5. Display Spectrum Analyzer Hasil Perekaman Sampel Tegangan

Setting alat ukur Spectrum Analyzer adalah sebagai berikut :

$\begin{array}{rlll}\text { Center Frequency } & =50 \mathrm{~Hz} \text { Video } B W \\ & =100 \mathrm{~Hz} & \\ \mathrm{~dB} \log / \mathrm{div} & =10 \mathrm{Resolution} & B W \\ & =30 \mathrm{kHz} & \\ \text { Span } & =10 \quad \mathrm{~Hz} \quad \text { Sweep } \\ & =1 \text { second }\end{array}$

Pergeseran frekuensi yang terekam yaitu 48.993 $\mathrm{Hz}-50.982 \mathrm{~Hz}$ dengan selisih pergeseran yaitu $1.989 \mathrm{~Hz}$.

\subsubsection{Pengukuran Bentuk Gelombang Input \& Output UPS}

Pengukuran ini dimaksudkan untuk melihat kondisi gelombang sinus ac input UPS maupun gelombang sinus hasil keluaran UPS, apakah memiliki cacat atau distorsi harmonik atau tidak. Bentuk gelombang yang akan diukur dalam hal ini adalah bentuk gelombang tegangan. UPS yang diukur adalah UPS $10 \mathrm{KVA}$ dengan menggunakan alat ukur oscilloscope dimana pengukuran dilakukan pada saat beban maksimal. Pengukuran pada UPS 40 KVA tidak dilakukan karena beresiko mengganggu kinerja perangkat stasiun bumi. Adapun hasil pengukuran tersebut dapat dilihat pada gambar di bawah ini :

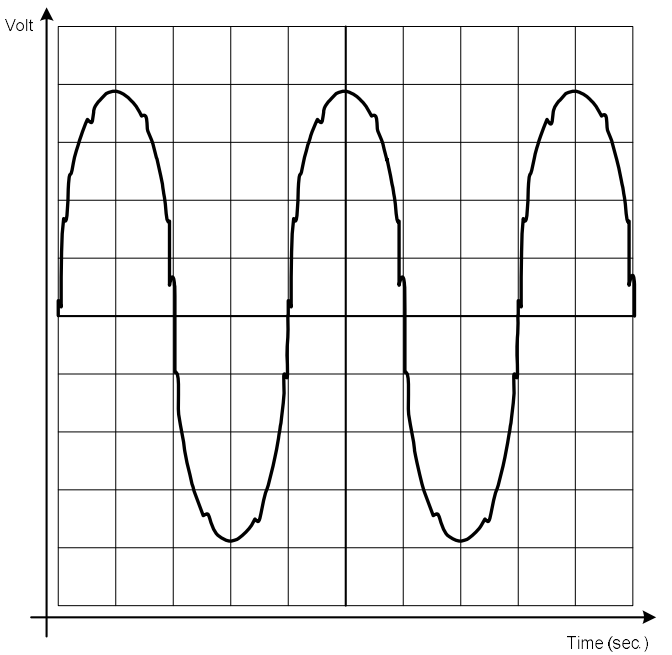

Gambar 3.6. Pengukuran Bentuk Gelombang Input UPS

Keterangan gambar :

Volt/div : 80 Volt/div

Time/div : $5 \mathrm{msec} . / \mathrm{div}$

Vmax $\quad: \quad \pm 312 \mathrm{~V}$

Frekuensi : $\frac{1}{4 \times 5 \times 10^{-3}}=50 \mathrm{~Hz}$

Seperti terlihat pada gambar di atas bahwa ternyata dengan penggunaan filter pasif harmonik sebelum MDP, masih terdapat distorsi harmonik pada tegangan input UPS. Sedangkan pada gambar di bawah memperlihatkan bentuk gelombang tegangan output UPS, dimana distorsi harmonik yang terdapat pada input UPS telah tersaring oleh filter, regulator maupun proses konversi bentuk gelombang ac pada UPS, walaupun juga masih tetap terdapat sedikit distorsi. Hal ini dapat terjadi kemungkinan karena banyaknya beban nonlinear yang dicatu oleh UPS 
ini dan/ataupun juga karena gangguan interferensi lain yang dapat saja masuk ke dalam jaringan distribusi apabila isolasi perkabelannya sudah kurang baik.

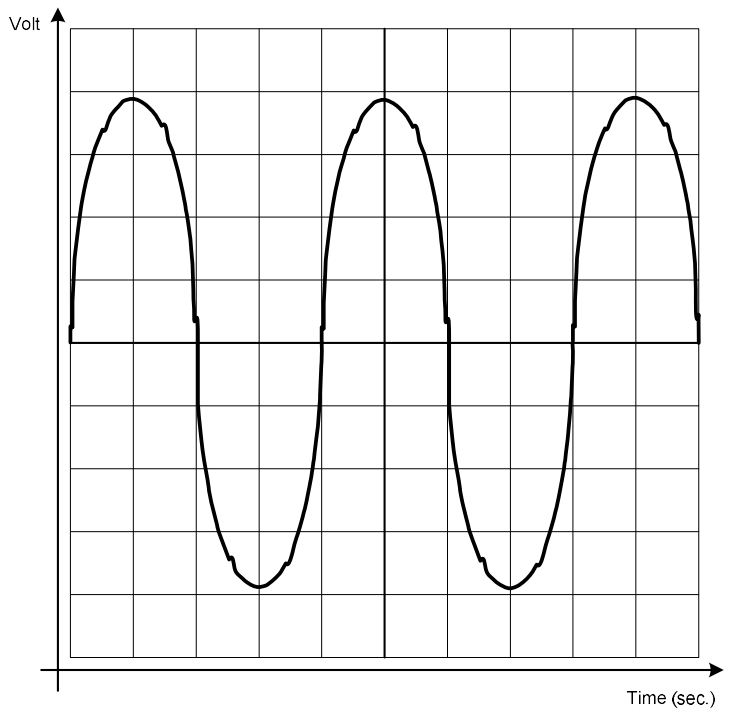

Gambar 3.7. Pengukuran Bentuk Gelombang Output UPS

Keterangan gambar :

$\begin{array}{lll}\text { Volt/div } & : & 80 \mathrm{Volt} / \mathrm{div} \\ \text { Time } / \mathrm{div} & : & 5 \mathrm{msec} . / \mathrm{div} \\ \text { Vmax } & : & \pm 312 \mathrm{~V} \\ \text { Frekuensi } & : & \frac{1}{4 \times 5 \times 10^{-3}}=50 \mathrm{~Hz}\end{array}$

\section{KESIMPULAN DAN SARAN}

\subsection{Kesimpulan}

Bahwa terlihat kondisi kualitas catu daya pada PT. Telkom Stasiun Bumi Sorong dapat dikatakan masih baik seperti ditunjukkan pada indikator parameter yang terukur yang masih di dalam toleransi persyaratan normal. Beberapa solusi kualitas daya yang telah diterapkan yaitu dengan menggunakan UPS untuk beban ac no break disertai dengan sistem backup yang cukup terjamin. Selain itu juga telah digunakan capacitor bank yang berfungsi menaikkan faktor daya agar energi listrik dapat terpakai optimal. Untuk mengatasi masalah harmonik, digunakan perangkat filter pasif yang dipasang sebelum input MDP dan sebelum input rectifier, walaupun masih terdapat harmonisa yang cukup mengganggu pada beban non essential.

Beberapa hambatan yang utama pada sistem kualitas daya pada PT. Telkom Stasiun Bumi Sorong, yaitu antara lain :

1. Kondisi perubahan pembebanan yang sangat cepat sehingga diperlukan monitoring dan pemeliharaan yang lebih intensif

2. Adanya resiko interferensi dengan gelombang microwave dari high power amplifier yang merupakan pancaran transmit stasiun bumi, sehingga sambungan-sambungan terminal maupun isolasi kabel harus betul-betul terjaga dengan baik

3. Banyaknya beban non linear yang dapat menghasilkan harmonisa, yang mau tidak mau beban non linear itu harus digunakan karena merupakan perangkat utama dari stasiun bumi.

\subsection{Saran}

Solusi yang paling efisien dan efektif untuk optimalisasi kualitas daya pada gedung instalasi yang perilaku bebannya bersifat turbulens adalah dengan menggunakan active conditioner yang bekerja secara selektif dan lebih "cerdas" dalam menanggapi kondisi perubahan beban karena perangkat ini bekerja dengan mikroprosesor yang mengatur komponen-komponen di dalamnya seperti komponen tangki RLC. Selain itu, di dalamnya terdapat banyak fungsi ganda seperti perbaikan faktor daya, penyeimbang tegangan fasa, filter harmonik, filter arus lebih, stabiliser tegangan dan lain sebagainya. Walaupun untuk investasi awalnya sangat besar tetapi hasil yang akan dicapai akan sangat memuaskan dengan umur kerja yang juga relatif cukup panjang. 


\section{DAFTAR PUSTAKA}

David Chapman, 2001, Journal of Harmonics : Causes and Effects, European Copper Institutes (ECI)

Divisi Pelatihan PT.Telkom Indonesia, 2001, Pengantar Teknik Catu Daya, Telkom Training Center, Bandung

Divisi Pelatihan PT.Telkom Indonesia, 1999, Troubleshooting UPS, Pusdiklat, Bandung

Hans De Keulenaer, 2002, Journal of Power Quality Self-Assesment Overview, European Copper Institutes (ECI)

Ken West, 2001, Journal of Harmonics : True RMS Measurements, Fluke- European Copper Institutes (ECI)

Mappa, A. (2017). Analisa Kerja Recloser untuk Memproteksi Jaringan Distribusi di PT. Pln (Persero) Area Sorong. Electro Luceat, 3(1), 5-9.

Rumalutur, S. (2017). Analisis Perbandingan Tap Konektor dengan Joint Press Konektor untuk Menekan Susut Jaringan Tegangan Rendah di PT Pln (Persero) Area Sorong. Electro Luceat, 3(1), 19-23.

Sunarno Ir., M.Eng, Ph.D, 2006, Mekanikal Elektrikal Lanjutan, Penerbit Andi, Yogyakarta

Tobi, M. D., \& VAN HARLING, V. N. (2017). PENGARUH PENGARUH OPTIMASI TRANSFORMATOR DAYA TERHADAP PERKEMBANGAN BEBAN FEEDER UNTUK MEMINIMALISASI GANGGUAN DAN DEFISIT BEBAN LISTRIK DI WILAYAH SORONG-PROVINSI PAPUA BARAT. Electro Luceat, 3(1), 1018.

Wasito S., 1997, Kamus Elektronika, PT. Gramedia Pustaka Utama, Jakarta 